\title{
PENGARUH MANAJEMEN PAJAK, PERTUMBUHAN PENJUALAN DAN UKU- RAN PERUSAHAAN TERHADAP NILAI PERUSAHAAN PADA PERUSAHAAN MANUFAKTUR DI BEI PERIODE 2014-2016
}

\section{THE EFFECT OF TAX MANAGEMENT, SALES GROWTH AND COMPANY SIZE ON COMPANY VALUE IN MANUFACTURING COMPANIES IN IDX 2014-2016 PERIOD}

\author{
Muhammad Hidayat ${ }^{1}$ \\ ${ }^{I}$ (Akuntansi, Ekonomi, Universitas Riau Kepulauan, Indonesia) \\ ${ }^{1}$ Hidayat.feunrika@gmail.com
}

\begin{abstract}
Abstrak
Tujuan dari penelitian ini adalah untuk menguji apakah manajemen pajak, pertumbuhan penjualan dan ukuran perusahaan berpengaruh terhadap nilai perusahaan. Penelitian ini dilakukan pada peruahaan sector manufaktur yang terdaftar di Bursa Efek Indonesia pada tahun 2014 sampai dengan tahun 2016. Jumlah sampel adalah 41 perusahaan yang dipilih dengan menggunakan metode purposive sampling. Teknik analisis yang digunakan adalah dengan regresi linear berganda untuk menguji hipothesis. Dari hasil analisis menunjukkan bahwa Manajemen Pajak dan Pertumbuhan Penjualan secara parsial berpengaruh positif dan tidak signifikan terhadap Nilai Perusahaan. Sedangkan Ukuran Perusahaan berpengaruh positif dan signifikan terhadap Nilai Perusahaan. Secara simultan Manajemen Pajak, Pertumbuhan Penjualan dan Ukuran Perusahaan tidak berpengaruh signifikan terhadap Nilai Perushaan,
\end{abstract}

Kata Kunci ; Manajemen Pajak, Pertumbuhan Penjualan dan Ukuran Perusahaan

\section{Abstract}

The aim of this study is to examine whether the Tax Management, Sales Growth and Firm Size influencing the Firm Value. This research was conducted at the manufacturing sector companies listed on the Indonesia Stock Exchange in 2014 until 2016. The number of samples was 41 companies selected using the purposive sampling method. The analysis technique used is multiple linear regression to test the hypothesis. The results of the analysis show that Tax Management and Sales Growth partially have a positive effect but not significantly influence towards Firm Value. Firm Size has a positive and significantly influence towards Company Value. Simultaneously Tax Management, Sales Growth and Company Size have no significantly influence towards the Firm Value,

Keywords ; Tax Management, Sales Growth and Company Size

\section{PENDAHULUAN}

Dapat dikatakan bahwa hamper semua perusahaan memiliki tujuan untuk meningkatkan nilai perusahaannya. Nilai perusahaan dapat menunjukkan suatu gambaran atau penilaian para investor terhadap keberhasilan perusahaan mengelola sumber dayanya. Harga saham perusahaan akan meningkat dan nilai perusahaan akan naik jika semakin banyak 
investor yang membeli saham perusahaan tersebut. Meningkatnya nilai perusahaan dapat membuat penilaian yang baik terhadap kinerja perusahaan maupun prospek perusahaan. Bila suatu perusahaan mempunyai nilai Price Book Value $>1$ maka harga saham perusahaan tersebut dinilai lebih tinggi daripada nilai bukunya, yang menggambarkan kinerja perusahaan tersebut semakin baik di mata investor.

Terdapat banyak faktor yang mempengaruhi nilai perusahaan berdasarkan pada penelitian yang telah dilakukan sebelumnya, nilai perusahaan dapat dipengaruhi oleh ukuran perusahaan (Gill dan Obradovich, 2012 Maryam, 2014), pertumbuhan penjualan (Mandalika, 2016 Pantow, 2015), sedangkan dalam Wibawa dan Wijaya (2010) berpendapat bahwa optimalisasi nilai perusahaan dapat dicapai melalui pelaksanaan fungsi manajemen keuangan, Ukuran perusahaan didefinisikan besar kecil suatu perusahaan dengan berbagai cara, seperti: ukuran pendapatan, jumlah karyawan, total aktiva, nilai pasar saham, dan total modal. Menurut Riyanto (2011:299), perusahaan yang besar dan sahamnya tersebar sangat luas, setiap perluasan modal tersebut memberikan pengaruh yang kecil terhadap kemungkinan hilangnya kontrol dari pihak dominan terhadap perusahaan yang bersangkutan. Maryam (2014) menemukan dalam penelitiannya bahwa ukuran perusahaan berpengaruh positif signifikan terhadap nilai perusahaan. Sejalan dengan Gill dan Obradovich (2012) menemukan bahwa ukuran perusahaan berpengaruh positif dan signifikan terhadap nilai perusahaan. Leverage merupakan modal yang berasal dari luar perusahaan yang sifatnya bekerja sementara di dalam perusahaan, dan bagi perusahaan yang bersangkutan modal tersebut adalah hutang, yang harus dikembalikan. Semakin tinggi hutang yang dimiliki, maka semakin kecil kemampuan perusahaan memenuhi kewajibannya kepada pemegang saham berupa dividen dan semakin buruk penilaian investor sehingga berdampak pada penurunan nilai perusahaan (Dj dkk, 2012. Penelitian yang dilakukan oleh Hansen dan Juniarti (2014) menemukan bahwa pertumbuhan penjualan tidak berpengaruh pada nilai perusahaan.

Melihat belum adanya konsistensi dari hasil penelitian-penelitian sebelumnya terkait variable terkait dalam mempengaruhi niali perusahaan maka masih menarik untuk dilakukan penelitian untuk mengetahui apakah manajemen pajak, ukuran perusahaan dan pertumbuhan penjualan berpengaruh terhadap nilai perusahaan, dan penelitian ini akan dilakukan pada perusahaan manufaktur yang terdaftar di BEI periode tahun 2014-2016.

\section{Rumusan Masalah}

Berdasarkan latar belakang diatas maka rumusan masalah dalam penelitian ini adalah sebagai berikut:

1. Apakah manajemen pajak berpengaruh terhadap nilai perusahaan?

2. Apakah pertumbuhan penjualan berpengaruh terhadap nilai perusahaan?

3. Apakah ukuran perusahaan berpengaruh terhadap nilai perusahaan?

4. Apakah manajemen pajak, pertumbuhan penjualan dan ukuran perusahaan berpengaruh terhadap nilai perusahaan? 


\section{TELAAH HIPOTESIS \\ PUSTAKA \\ DAN}

\section{Signaling Theory}

Teori ini pertama kali dikemukakan oleh Spence pada tahun 1973, yang mengemukakan bagaimana sebuah perusahaan memberikan sinyal kepada pengguna laporan keuangan. Sinyal tersebut dapat berupa sebuah informasi mengenai apa yang sudah dilakukan manajemen untuk merealisasikan keinginan pemilik. Teori sinyal digunakan untuk menjelaskan suatu informasi dapat dimanfaatkan perusahaan untuk memberi sinyal positif maupun negatif kepada pemakainya. Teori sinyal menyatakan bahwa pihak internal perusahaan yang memiliki sebuah informasi yang lebih baik tentang perusahaannya akan terdorong untuk mengungkapkan informasi tersebut kepada calon investor dimana perusahaan dapat menaikkan nilai perusahaan melalui laporan tahunannya (Scott, 2012:475).

\section{Nilai Perusahaan}

Nilai perusahaan merupakan persepsi investor terhadap tingkat keberhasilan perusahaan yang dikaitkan dengan harga saham. Harga saham yang tinggi membuat nilai perusahaan juga tinggi. Nilai perusahaan yang tinggi akan membuat pasar percaya tidak hanya pada kinerja perusahaan saat ini namun pada prospek perusahaan di masa depan (Wijaya dan Sedana, 2015). Nilai perusahaan juga didefinisikan sebagai nilai pasar. Nilai pasar merupakan persepsi pasar yang berasal dari investor, kreditur, dan stakeholder lain terhadap kondisi perusahaan yang tercermin pada nilai pasar saham perusahaan yang bisa menjadi ukuran nilai perusahaan (Haryadi, 2016). Dalam penelitian ini nilai perusahaan diproksikan dengan Price Book Value (PBV).

\section{Manajemen Pajak}

Tindakan manajemen pajak merupakan hal yang biasa dilakukan oleh perusahaan, tindakan ini dilakukan perusahaan dengan tujuan meminimalisasi jumlah kena pajak yang didapat oleh perusahaan. Menurut Nugraha dan Meiranto (2015) agresivitas adalah kegiatan perencanaan pajak (taxplanning) semua perusahaan yang terlibat dalam usaha mengurangi tingkat pajak yang efektif. Tax planning adalah proses pengendalian tindakan agar terhindar dari konsekwensi pengenaan pajak yang tidak dikehendaki (Kuriah dan Asyik, 2016). Pemerintah melalui Direktorat Jenderal Pajak selalu berusaha untuk memperbaharui peraturan-peraturan perpajakan untuk meningkatkan penerimaan pajak. Namun, di sisi lain perusahaan selalu berusaha untuk menghemat pembayaran pajak yang dapat dilakukan dengan cara yang legal, yaitu agresivitas pajak ( Siregar dan Widyawati, 2016). Perusahaan menganggap pajak sebagai biaya karena dengan membayar pajak berarti mengurangi jumlah laba bersih yang akan diterima. Oleh karena itu, perusahaan diprediksi akan melakukan tindakan pajak secara agresif yang dapat mengurangi biaya pajak tersebut. Manajemen pajak dapat diukur dengan menggunakan Net Profit Margin (NPM) dan Effective Tax Rate (ETR). Net Profit Margin (NPM) dihitung dengan cara membandingkan NPM perusahaan dengan NPM dari industri perusahaan tersebut. Sedangkan Effective Tax Rate (ETR) dihitung dengan cara membagi total pajak yang dibayarkan dengan laba sebelum pajak (Adisamartha \& Noviari, 2015).

\section{Pertumbuhan Penjualan}

Pertumbuhan penjualan adalah kenaikan jumlah penjualan terhadap tahun sebelumnya.Pertumbuhan jualan ini juga adalah merupakan indicator terjadinya 
pertumbuhan perusahaan perusahaan yang merupakan tolak ukur keberhasilan perusahaan. Keberhasilan tersebut menjadi tolak ukur investasi untuk pertumbuhan pada masa yang akan datang. Pertumbuhan perusahaan dapat ditunjukkan pertumbuhan aset yang dimiliki perusahaan. Semakin besar aset diharapkan semakin besar hasil operasional yang dihasilkan perusahaan. Selain itu indikator pertumbuhan perusahaan dapat dilihat dari kenaikan penjualan dari tahun ke tahun. Pertumbuhan penjualan adalah indikator penting dari penerimaan pasar atas produk atau jasa suatu perusahaan, dimana pendapatan yang dihasilkan dari penjualan akan dapat digunakan untuk mengukur tingkat pertumbuhan penjualan (Meidiyustiani, 2016).

$$
\text { Pertumbuhan Penjualan }=\frac{\text { penjualant }- \text { penjualan }(t-1)}{\text { penjualan }(t-1)}
$$

\section{Ukuran Perusahaan}

Perusahaan memiliki dua jenis kategori, yaitu perusahaan berskala kecil dan perusahaan berskala besar. Dalam Nurminda, Isynuwardhana, dan Nurbaiti (2017) disebutkan bahwa ukuran perusahaan adalah suatu skala dimana dapat diklasifikasikan besar kecil perusahaan menurut berbagai cara, antara lain total aktiva, log size, penjualan, dan nilai pasar saham. Dalam penelitian ini, ukuran perusahaan didasarkan pada total aset perusahaan karena dianggap lebih stabil dan mencerminkan ukuran perusahaan. Menurut Prastuti dan Sudiartha (2016), semakin besar skala perusahaan atau ukuran dari perusahaan maka pendanaan yang bersifat internal maupun eksternal akan semakin mudah untuk diperoleh.

\section{Pengembagan Hipotesis}

Pengaruh Perencanaan Pajak Terhadap Nilai Perusahaan
Wahab et.al. (2012) dan Hanlon dan Slemrod (2009). Menemukan bahwa perencanaan pajak berpengaruh negatif terhadap nilai perusahaan. Sedangkan aebagian peneliti menemukan bahwa perencanaan pajak berpengaruh positif terhadap nilai perusahaan yaitu antaralain adalah Wilson (2009), Wang (2010) dan Martani et.al. (2012). Sedangkan Desai et.al. (2009) menemukan pengaruh namun tidak signifikan antara perencanaan pajak terhadap nilai perusahaan untuk perusahaan di Amerika. Dari beberapa hasil penelitian terdahulu tersebut menunjukkan bahwa pengaruh perencanaan pajak dapat berdampak positif dan negative terhadap nilai perusahaan.

H1: Perencanaan pajak berpengaruh positif terhadap nilai perusahaan.

\section{Pengaruh Ukuran Perusahan ter- hadap Nilai PERUSahaAN}

Ukuran perusahaan merupakan suatu skala dimana mengklasifikasikan besar kecil suatu perusahaan dengan berbagai cara seperti: ukuran pendapatan, jumlah karyawan, total aktiva, nilai pasar saham, dan total modal. Semakin besar ukuran perusahaan, semakin besar pula kecenderungan investor untuk memiliki saham tersebut sehingga mengakibatkan kenaikan harga saham. Adanya kenaikan harga saham tersebut menyebabkan naiknya Price Book Value (PBV) atau nilai perusahaan. Perusahaan yang besar dapat menyebabkan pasar mau membayar lebih mahal untuk mendapatkan sahamnya karena percaya akan mendapatkan pengembalian yang menguntungkan dari perusahaan tersebut.

$\mathrm{H} 2$ : Ukuran perusahaan berpengaruh positif terhadap nilai perusahaan 


\section{Pengaruh Pertumbuhan Penjualan TERHADAP Nilai PERUSAHAAN}

Pertumbuhan penjualan mencerminkan keberhasilan investasi di masa lalu dan dapat dijadikan sebagai prediksi pertumbuhan di masa depan. Apabila pertumbuhan penjualan perusahaan positif dan meningkat, maka mengindikasikan nilai perusahaan yang besar dan merupakan harapan bagi pemilik perusahaan. Pertumbuhan penjualan dipengaruhi beberapa faktor kondisi, kemampuan penjual, dan kondisi pasar.

H3 : Pertumbuhan penjualan berpengaruh positif terhadap nilai perusahaan.

Pengaruh manajemen pajak, pertumbuhan penjualan dan ukuran perusahaan terhadap nilai perusahaan.

Sebagaimana pembahasan diatas telah disampaikan pengaruh masing-masing variable bebas yaitu manajemen pajak, pertumbuhan penjualan, dan ukuran perusahaan terhadap variable terikat yaitu nilai perusahaan, sehingga hipotesisi pengaruh secara simultan dapat disimlukan sebagai beriku:

H4 : Manajemen pajak, pertumbuhan penjualan dan ukuran perusahaan berpengaruh positif terhadap nilai perusahaan.

\section{METODE PENELITIAN}

\section{Jenis Dan Pengumpulan Data}

Data penelitian ini menggunakan jenis data sekunder, yaitu laporan keuangan perusahaan manufaktur yang terdaftar di Bursa Efek Indonesia pada periode tahun 2014-2016. pemgumpulan data dilakukan dengan mengunduh langsung dari situs resmi Bursa Efek Indonesia (www.idx.co.id).

\section{Populasi dan Sampel Penelitian}

Populasi dalam penelitian ini adalah perusahaan manufaktur yang terdaftar di Bursa Efek Indonesia pada tahun 2014-2016. Jumlah sampel dalam penelitian ini adalah 41perusahaan manufaktur yang diperoleh dengan menggunakan purposive sampling, dengan kriteria sebagai berikut :

1. Perusahaan manufaktur yang terdaftar di Bursa Efek Indonesia periode tahun 2014 samapai dengan tahun 2016.

2. Perusahaan yang mempublikasi laporan keuangannya secara lengkap secara berturut-turut pada periode tahun 2014-2016.

3. Perusahaan memiliki data lengkap untuk kebutuhan penelitian ini dan menggunakan mata uang Rupiah (Rp).

\section{Teknik dan Analisis Data Analisis Deskriptif}

Analisis deskriptif ini bertujuan untuk mendeskripsikan suatu data menjadi lebih ringkas dan mudah dipahami yang dilihat dari nilai rata-rata, nilai minimal, nilai maksimal dan standar deviasi masing- masing variabel.

1. Uji Asumsi Klasik

Uji Asumsi klasik ini dilakukan untuk menilai apakah di dalam sebuah model regresi linear terdapat masalah-masalah asumsi klasik.

2. Analisis Regresi Linear

Analisis regresi linier ini bertujuan untuk menguji pengaruh dua variabel independen atau lebih terhadap variabel dependen secara bersama-sama atau secara parsial. Analisis ini juga untuk mengetahui arah hubungan antara variabel independen dengan variabel dependen..Analisis regresi linear ini dilakukan dengan alat bantu statistic yaitu program IBM SPSS yang digunakan untuk menguji hipotesis sebagai berikut:

$$
\mathrm{Y}=\beta 0+\beta 1 \mathrm{X} 1+\beta 2 \mathrm{X} 2+\beta 3 \mathrm{X} 3+\varepsilon
$$

Keterangan: 


$$
\begin{aligned}
& \beta 0=\text { Konstanta } \\
& \beta 1=\text { Koefisien regresi untuk X1 } \\
& \beta 2=\text { Koefisien regresi untuk X2 } \\
& \beta 3=\text { Koefisien regresi untuk X3 } \\
& \varepsilon t=\text { Standar error } \\
& Y=\text { Nilai Perusahaan } \\
& X 1=\text { Manajemen Pajak } \\
& X 2=\text { Pertumbuhan Penjualan } \\
& X 3=\text { Ukuran Perusahaan }
\end{aligned}
$$

\section{HASIL DAN PEMBAHASAN}

Hasil Analisis Deskriptif

Tabel 4.1. Deskriptive

\begin{tabular}{|l|r|r|r|r|r|r|}
\hline & N & Minimum & Maximum & \multicolumn{1}{|c|}{ Mean } & Std. Deviation & Variance \\
\hline SG & 123 & -97 & 1,46 & -0107 &, 40625 &, 165 \\
TM & 123 &, 01 & 2,69 &, 9181 &, 65409 &, 428 \\
PBV & 123 &, 00 & 8,84 & 1,5775 & 1,73887 & 3,024 \\
SIZE & 123 & 11,13 & 14,85 & 12,3713 &, 72557 &, 526 \\
ValidN (listwise) & 123 & & & & & \\
\hline
\end{tabular}

Dari hasil statistik deskriptif sebagaimana table 4.1 dapat dilihat bahwa nilai pertumbuhan penjualan (SG) memiliki nilai minimum -0.97 sedangkan nilai pertumbuhan penjualan tertinggi adalah 1.46 dan nilai ratarata adalah -0.1, data ini menunjukkan bahwa tidak banyak perusahaan yang penjualannya bertumbuh dalam periode penelitian ini. sedangkan nilai manajemen pajak (TM) memiliki nilai terendah 0.01 sedangkan nilai maksimum adalah 2.69 dengan nilai rata-rata 0.92. Adapun ukuran perusahaan (SIZE) memiliki nilai terendah 11.13 dan nilai tertinggi 14.85 dan nilai rata-rata 12.37. Hampir semua variable menunjukkan bahwa nilai standar deviasi lebih besar dari nilai rata-ratanya, ini menunjukkan bahwa datanya sangat bervariasi.

\section{Hasil Asumsi Klasik}

Uji Normalitas

Table 4.2 Uji Normalitas

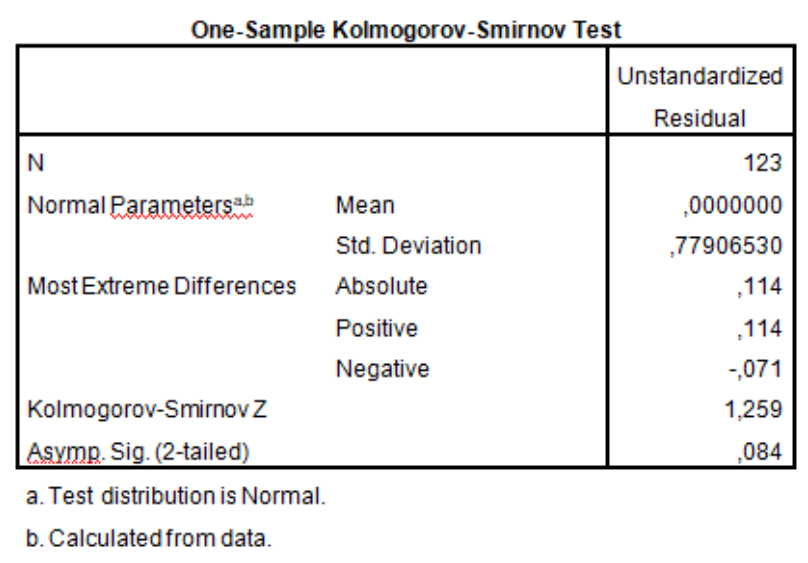

Tabel 4.2 menunjukkan bahwa nilai asymp Sig (2tailed) $=0,084$, nilai tersebut lebih besar dari 0,05 , yang berarti distribusi data normal. Hal ini dapat diartikan bahwa sampel penelitian sejumlah 123 sudah benar-benar mewakili populasi penelitian.

\section{Multikolinieritas}

Tabel 4.3 Uji Multikolinieritas

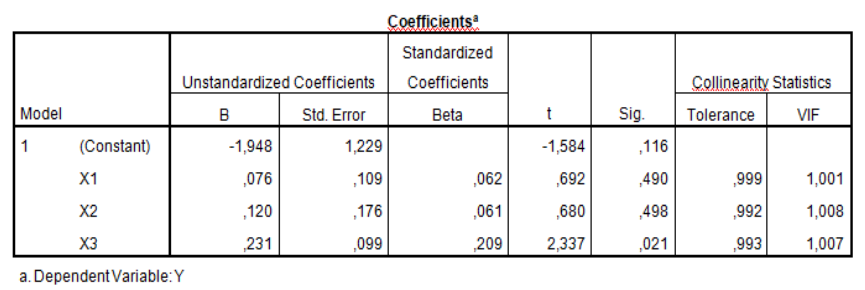

Tabel 4.4 menunjukkan bahwa masing-masing variabel independen memiliki nilai VIF $<10$, dan nilai Tolerance $>0.1$ hal ini dapat diarikan bahwa data penelitianini bebas dari multikolinieritas, sehingga asumsi multikolinieritas terpenuhi.Hal ini menunjukkan bahwa tidak ada hubungan antar variabel independen.

\section{Heteroskedastisitas}

Tabel 4.4 Uji Heteroskedastisitas

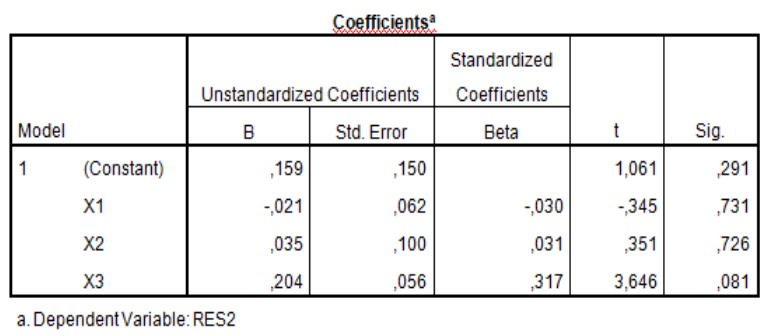


Tabel 4.4 menunjukkan bahwa masing-masing variabel independen memiliki nilai Sig $>0,05$, yang berarti bebas heteroskedastisitas. Hasil ini menujukkan bahwa asumsi heteroskedastisitas terpenuhi, yaitu variansi dari residual satu pengamatan ke pengamatan lain tetap.

\section{Autokorelasi}

Tabel 4.5 Uji Autokorelasi

\begin{tabular}{|l|c|r|r|r|r|}
\hline Model & $\mathrm{R}$ & $\mathrm{R}$ Square & $\begin{array}{c}\text { Adjusted } \mathrm{R} \\
\text { Square }\end{array}$ & $\begin{array}{c}\text { Std. Error of the } \\
\text { Estimate }\end{array}$ & Durbin-Watson \\
\hline 1 &, $231^{\mathrm{a}}$ &, 053 &, 029 &, 78882 & 1,797 \\
\hline
\end{tabular}
a. Predictors: (Constant), X3, X1, X2
b. Dependent Variable:Y

Uji autokorelasi bertujuan untuk mengetahui ada atau tidaknya korelasi antara kesalahan pengganggu pada periode $t$ dengan kesalahan pengganggu pada periode $\mathrm{t}-1$ (sebelumnya). Hal ini dilakukan dengan uji Durbin-Watson diperoleh nilai DW 1,797. Nilai du ( $\mathrm{n}=123 ; \alpha=0,05 ; \mathrm{k}=3)$ sebesar 1,755. Dengan demikian, nilai DW ini berada diantara du dan 4-du, yang berarti model regresi bebas autokorelasi.

Hasil Analisis Regresi Berganda

Hasil Koefisien Determinasi

\section{Tabel 4.6 Uji Koefisien Determinasi}

\begin{tabular}{|c|c|c|c|c|c|}
\hline \multicolumn{6}{|c|}{ Model Summary } \\
\hline Model & $\mathrm{R}$ & R Square & $\begin{array}{l}\text { Adjusted R } \\
\text { Square }\end{array}$ & $\begin{array}{l}\text { Std. Error of the } \\
\text { Estimate }\end{array}$ & Durbin-Watson \\
\hline 1 & $231^{a}$ & 053 & 029 & ,78882 & 1,697 \\
\hline
\end{tabular}

a. Predictors: (Constant), X3, X1, X2

b. Dependent Variable: $Y$

Variabel hanya mempengaruhi 5,3\% terhadap nilai perusahaan.

Tabel 4.6 menunjukkan Adjusted $R$ Square $=0,053$ hal ini menunjukkan bahwa variabel manajeman pajak, pertumbuhan penjualan dan ukuran perusahaan hanya memberikan pengaruh secara bersama-sama sebesar 5,3\% sedangkan $94.7 \%$ ditentukan oleh variabel lain.

Hasil Uji T (Uji Hipotesis)

Tabel 4.7 Uji Hipotesis Uji T

\begin{tabular}{|c|c|c|c|c|c|c|}
\hline \multicolumn{7}{|c|}{ Coefficients $^{\mathrm{a}}$} \\
\hline \multirow{2}{*}{\multicolumn{2}{|c|}{ Model }} & \multicolumn{2}{|c|}{ Unstandardized Coefficients } & \multirow{2}{*}{$\begin{array}{c}\text { Standardized } \\
\text { Coefficients } \\
\text { Beta } \\
\end{array}$} & \multirow[b]{2}{*}{$t$} & \multirow[b]{2}{*}{ Sig. } \\
\hline & & $\mathrm{B}$ & Std. Error & & & \\
\hline \multirow[t]{4}{*}{1} & (Constant) &, 361 &, 266 & & 1,357 & ,177 \\
\hline & $\mathrm{X} 1$ &, 076 & , 109 &, 062 & ,692 &, 490 \\
\hline & $\mathrm{X} 2$ &, 120 & , 176 &, 061 &, 680 &, 498 \\
\hline & $\mathrm{X} 3$ & 231 &, 099 & 209 & 2,337 &, 021 \\
\hline
\end{tabular}

a. DependentVariable: $Y$

Berdarakan table 4.7 hasil uji $\mathrm{T}$ dapat dijelaskan sebagai berikut:

1. Manajemen Pajak (X1) diperoleh nilai Signifikasni $=0,490$ atau Sig $>0.05$, dan nilai $\beta=0.076$ sehingga dapat disimpulkan bahwa manajemen pajak berpengaruh positif dan tidak signifikan terhadap Nilai Peusahaan.

2. Pertumbuhan Penjualan (X2) diperoleh nilai Signifikasni $=0,498$ atau Sig $>0.05$, dan nilai $\beta=0.120$ sehingga dapat disimpulkan bahwa manajemen pajak berpengaruh positif dan tidak signifikan terhadap Nilai Peusahaan.

3. Ukuran Perusahaan (X3) diperoleh nilai Signifikasni $=0,021$ atau Sig $<0.05$, dan nilai $\beta=0.20$ dengan demikian maka dapat disimpulkan bahwa Ukuran Perusahaan mempengaruhi Nilai Perusahaan secara positif dan signifikan.

Hasil Uji F (Uji Hipotesis)

Tabel 4.8 Uji Hipotesis - Uji F

\begin{tabular}{|c|c|c|c|c|c|c|}
\hline \multicolumn{7}{|c|}{ ANOYA ${ }^{\circ}$} \\
\hline & & Sum of Squares & df. & Mean Square & $\mathrm{F}$ & Sig. \\
\hline \multirow[t]{3}{*}{1} & Regression & 4,174 & 3 & \multirow{3}{*}{$\begin{array}{r}1,391 \\
, 622\end{array}$} & \multirow[t]{3}{*}{2,236} & \multirow[t]{3}{*}{, $088^{a}$} \\
\hline & Residual & 74,047 & 119 & & & \\
\hline & Total & 78,221 & 122 & & & \\
\hline
\end{tabular}


Hasil uji F sebagaimana table 4.8 diatas dapat dilihat bahwa nilai Signifikansi adalah 0.088 atau Sig>0.05 sehingga dapat disimpulkan bahwa Manajemen Pajak, Pertumbuhan Penjualan dan Ukuran Perusahaan secara bersama-sama berpengaruh positif tetapi tidak berpengaruh secara signifikan terhadap nilai Perusahaan.

\section{KESIMPULAN DAN SARAN Kesimpulan}

Kesimpulan penelitian sebagai berikut:

1. Manajemen Pajak berpengaruh posisitf dan tidak signifikan terhadap Nilai Perusahaan.

2. Pertumbuhan Penjualan berpengaruh positif dan tidak signifikan terhadap Nilai Perusahaan.

3. Ukuran Perusahaan berpengaruh positif dan signifikan terhadap Nilai Perusahaan.

4. Manajemen Pajak, Pertumbuhan Penjualan dan Ukuran Perusahaan secara simultan berpengaruh tidak signifikan terhadap Nilai Perusahaan.

Saran

Untuk peneliti selanjutnya disarankan dapat menambah jangka waktu penelitian misalnya menjadi 4 tahun atau meneliti sektor usaha lainnya di Bursa Efek Indonesia. Peneliti selanjutnya juga disarankan untuk meneliti variable lainnya seperti variabel Kepemilikan Asing, Kualitas Laba, Profitabilitas, Kualitas Audit, dan variable-variabel lainnya sebagai faktor yang diperkirakan akan dapat mempengaruhi Nilai Perusahaan.

\section{DAFTAR PUSTAKA}

Adisamartha, Ida Bagus Putu Fajar dan Noviari Naniek. 2015. Pengaruh
Likuiditas, Leverage, Intensitas Persediaan dan Intensitas Aset Tetap Pada Tingkat Agresivitas Wajib Pajak Badan. E-Jurnal Akuntansi Universitas Udayana. Vol. 13, No. 3. ISSN : 2303 - 101

Afza, Talat dan Syamsa Tahir. 2012. Determinants of Price-Earnings Ratio: The Case of Chemical Sector of Pakistan. International Journal of Academic Research in Business and Social Sciences, 8: 331- 343.

Bhayo, Mujeeb U Rehman, Ali Khan mubashir, and Shahza Shaikh Raja. 2011. An Idiosyncratic Explanation of Earning Price Ratio Based on Financial StatementAnalysis. International Journal of Business and Social Science, (9), 243-249.

Chen, Li-Ju. 2011. The Influence of Profitability on Firm Value with Capital Structure as The Mediator and Firm Size and Industry as Moderators. Investment Management and $\mathrm{Fi}$ nancial Innovations, 8(3): 121-128.

Cheung, W. M., Chung, R., \& Fung, S. 2015. The effects of stock liquidity on firm value and corporate governance: Endogeneity and the REIT experiment. Journal of Corporate Finance, 35, 211-231.

Dj, Alfredo Mahendra, Luh Gede Sri Artini dan A. A. Gede Suarjaya. 2012. Pengaruh Kinerja Keuangan Terhadap Nilai Perusahaan pada Perusahaan Manufaktur di Bursa Efek Indonesia. Jurnal Manajemen, Strategi Bisnis, dan Kewirausahaan, 6 (2): 130-138. 
Efni, Yulia; Djumilah; Ubud dan Mintarti. 2012. Price Earning Ratio, Keputusan Pendanaan, dan Kebijakan Dividen: Pengaruhnya terhadap Nilai Perusahaan. Jurnal Aplikasi Manajemen. 10(1).

Ernawati, D. 2016. Pengaruh Profitabilitas, Leverage Dan Ukuran Perusahaan Terhadap Nilai Perusahaan. Jurnal Ilmu \& Riset Akuntansi, 4(4)., 2004. Manajemen Keuangan.

Gill, Amarjit dan Obradovich, John. 2012. The Impact of Corporate Governance and Financial Leverage on the Value of American Firms. International Research Journal of Finance and Economics . ISSN 1450 - 2887 Issue 91.

Hansen V. dan Juniarti, 2014. Pengaruh Family Control, Size, Sales Growth, dan Leverage Terhadap Profitabilitas dan Nilai Perusahaan Pada Sektor Perdagangan, Jasa, Dan Investasi. Business Acounting Review, Vol. 2, Hal. 121-130.

Haryadi (2016) Pengaruh size perusahaan, keputusan pendanaan, profitabilitas dan keputusan investasi terhadap nilai perusahaan. Jurnal Akuntansi, Universitas Serang Raya. Vol.3 (No.2), hal $84-100$.

Meidiyustiani, Rinny. 2016. Pengaruh Modal Kerja, Ukuran Perusahaan, Pertumbuhan Penjualan dan Likuiditas Terhadap Profitabilitas pada
Perusahaan Manufaktur Sektor Industri Barang Konsumsi yang Terdaftar di Bursa Efek Indonesia (BEI) Periode Tahun 2010 - 2014. Jurnal Akuntansi dan Keuangan. Vol. 5. No.2.

Mulyati, H., \& Kalbuana, N. (2016). Pengaruh Leverage, Profitabilitas, dan Ukuran Perusahaan Terhadap Nilai Perusahaan (Studi Empiris pada Perusahaan Garment dan Textile yang terdaftar di Bursa Efek Indonesia Tahun 2011- 2015).

Prasetyorini, Bhekti Fitri. 2013. Pengaruh Ukuran Perusahaan, Leverage, Price Earning atio dan Profitabilitas terhadap Nilai Perusahaan. Jurnal Ilmu Manajemen, 1(1), 183-196.

Rahayu, Fitri Dwi dan Asandimitra, Nadia. 2014. Pengaruh Ukuran Perusahaan,Leverage, Profitabilitas, Kebijakan Dividen Dan Cash Holding Terhadap Nilai Perusahaan Pada Sektor Manufaktur. Jurnal Ilmu Manajemen, 2(2).

Siregar,R.dan Widyawati,D.(2016).Pengaruh Karakteristik Perusahaan Terhadap Penghindaran Pajak pada Perusahaan Manufaktur di BEI.Jurnal Ilmu dan Riset Akuntansi, Vol. 5, (No. 2), hal 1-17.

Swingly, C \& Sukartha, I.M. 2015. Pengaruh Karakter Eksekutif, Komite Audit, Ukuran Perusahaan, Leverage, dan 
Sales Growth pada Tax Avoidance. E-Jurnal Akuntansi Universitas Udayana, Vol. 10 (1): 47-62.

Wijaya, B. I., dan Sedana, I. B. 2015. "Pengaruh Profitabilitas Terhadap Nilai Perusahaan (Kebijakan Dividen Dan Kesempatan Investasi Sebagai Variabel Mediasi).” E-Jurnal Manajemen Universitas Udayana, 4 (12). 